\title{
Zinc, copper and manganese availability in soils treated with alkaline sewage sludge from Paraná state (Brazil)
}

\author{
Disponibilidade de $\mathrm{Zn}$, Cu e Mn em solos tratados com lodo de esgoto \\ alcalinizado do estado do Paraná (Brasil)
}

\author{
Maristela Dalpisol ${ }^{1}$, Beatriz Monte Serrat ${ }^{2}$, Antonio Carlos Vargas Motta ${ }^{2 \star}$, Giovana Clarice Poggere ${ }^{3}$, \\ Simone Bittencourt ${ }^{4}$, Julierme Zimmer Barbosa ${ }^{1}$
}

\begin{abstract}
1 Universidade Federal do Paraná/UFPR, Programa de Pós-Graduação em Ciência do Solo, Curitiba, PR, Brasil ¿Universidade Federal do Paraná/UFPR, Departamento de Solos e Engenharia Agrícola, Curitiba, PR, Brasil ${ }^{3}$ Universidade Federal de Lavras/UFLA, Programa de Pós-Graduação em Ciência do Solo, Lavras, MG, Brasil ${ }^{4}$ Companhia de Saneamento do Paraná/SANEPAR, Unidade de Serviço de Esgoto, Curitiba, PR, Brasil

*Corresponding author: mottaufpr@gmail.com

Received in September 18, 2016 and approved in October 31, 2016
\end{abstract}

\begin{abstract}
In Paraná, most of the sludge generated in sewage treatment plants is subjected to the prolonged alkaline stabilization process. Although it is known that the alkaline sewage sludge contains micronutrients such as Zn, Cu and Mn, little is known about the availability of these elements in soils treated with this type of sewage sludge. Thus, the objective of the study was to evaluate the influence of alkaline sewage sludge from Paraná on Zn, Cu and Mn availability in soils. Twenty sewage treatment plants were selected throughout Paraná, where alkaline sewage sludge and the most representative agricultural soil of the each region were collected. Each soil was incubated for 60 days with alkaline sewage sludge rates $\left(0,10,20,40\right.$, and $\left.80 \mathrm{Mg} \mathrm{ha}^{-1}\right)$ from their region. Subsequently, Zn, Cu and Mn availability was determined using the Mehlich-1 extractant. The alkaline sewage sludge increased $\mathrm{Zn}$ availability and decreased Mn availability in most soils. Cu showed intermediate results, with increased availability, primarily in medium texture soils and decrease in most of the clayey soils. In soils with $\mathrm{pH}$ close to ideal for the plant growth, the alkaline sewage sludge rate should be carefully calculated so that there is no excessive increase in the $\mathrm{pH}$ and $\mathrm{Zn}, \mathrm{Cu}$ and $\mathrm{Mn}$ imbalance.
\end{abstract}

Index terms: Acid soils; organic residues; recycling; micronutrients.

\begin{abstract}
RESUMO
No Paraná, a maioria do lodo de esgoto gerado em estações de tratamento é submetida ao processo de estabilização alcalina prolongada. Embora seja conhecido que o lodo de esgoto alcalinizado contém micronutrientes como Zn, Cu e Mn, pouco se conhece sobre a disponibilidade desses elementos em solos tratados com esse tipo de lodo de esgoto. Assim, o objetivo do estudo foi avaliar a influência de lodos de esgoto alcalinizados do estado do Paraná sobre a disponibilidade de Zn, Cu e Mn no solo. Foram selecionadas vinte estações de tratamento de esgoto ao longo do Paraná, onde foram coletadas amostras de lodo de esgoto alcalinizado e amostras do solo agrícola mais representativo da região. Cada solo foi incubado por 60 dias com doses de lodo de esgoto (0, 10, 20, 40, e 80 Mg ha-1) da sua região. Posteriormente, foi determinada a disponibilidade de Zn, Cu e Mn no solo usando o extrator Mehlich-1. A aplicação de lodo de esgoto alcalinizado ao solo aumentou a disponibilidade de Zn e diminuiu a disponibilidade de Mn na maioria dos solos. Já o Cu apresentou resultados intermediários, com aumento de disponibilidade basicamente em solos de textura média e com diminuição para a maioria dos solos muito argilosos. Em solos com pH próximo ao ideal para o cultivo agrícola, a dose de lodo de esgoto alcalinizado deve ser cuidadosamente calculada para que não ocorra o aumento excessivo do pH e desbalanço nos teores de $\mathrm{Zn}$, Cu e Mn.
\end{abstract}

Termos para indexação: Solos ácidos; resíduos orgânicos; reciclagem; micronutrientes.

\section{INTRODUCTION}

Among the micronutrients, $\mathrm{Zn}$ is the most deficient in the natural condition of Brazilian soils, requiring supplementation in new areas via fertilization to allow plant cultivation. Although less common, $\mathrm{Cu}$ deficiency occurs mainly in sandy or organic soils (Motta et al., 2007). The specific adsorption is one of the most important mechanisms for controlling $\mathrm{Zn}$ and $\mathrm{Cu}$ availability in soil. The $\mathrm{Zn}$ and $\mathrm{Cu}$ adsorption capacity varies depending on the texture, mineralogy, organic matter and pH (Arias et al., 2006; Casagrande; Soares; Mouta, 2008; Smolders et al., 2012), thus, the availability of these nutrients may vary from soil to soil. On the other hand, under natural acid soil condition the Mn usually has high availability, which may promote plants toxicity (Millaleo et al., 2010). 
The use of organic residues on agricultural land has been increasingly common (Barcellos et al., 2015; Mondal et al., 2015). In Brazil, the states that most use sewage sludge for agricultural purposes are: Paraná, São Paulo and Rio Grande do Sul (Sampaio, 2010). Between 2007 and 2010 the sewage treatment plants in the Curitiba metropolitan region allocated $33,404 \mathrm{Mg}$ (dry basis) of sanitized sewage sludge for use on 2,288 hectares of agricultural areas (Bittencourt et al., 2014). Studies have found that the sewage sludge have significant amounts of some elements essential to plants, such as $\mathrm{Zn}$ and $\mathrm{Cu}$ (Fia; Matos; Aguirre, 2005; Yada et al., 2015), and which can improve physical and biological soil properties (Bonini; Alves; Montanari, 2015; Mondal et al., 2015).

The chemical composition of sewage sludge varies with origin, collection time and type of treatment to which it was submitted (Healy et al., 2016). In Paraná, most of the sewage sludge is subjected to sanitization by a prolonged alkaline stabilization process (addition of lime aimed at raising the $\mathrm{pH}$ of the mixture to 12 and a curing period of 30 days) (Paraná, 2009). Thus, when applied to agricultural land, the alkaline sewage sludge has double action, it increases the soil pH (Berton; Nogueira, 2010; Poggere et al., 2012) and can be a micronutrients source (Smolders et al., 2012; Bittencourt et al., 2014). However, unlike mineral fertilizer, the chemical composition of sewage sludge is quite variable, which results in a high degree of uncertainty regarding the micronutrient supply. Thus, the objective of this study was to evaluate the influence of alkaline sewage sludge from Paraná as to $\mathrm{Zn}, \mathrm{Cu}$ and $\mathrm{Mn}$ availability in soils.

\section{MATERIAL AND METHODS}

The Sanitation Company of Paraná (SANEPAR) is divided into twenty sectors throughout the Paraná State (Brazil); and in each sector there are several sewage treatment plants (STPs). In this study, for each of the twenty SANEPAR sectors, the STP from sector municipal headquarters was selected, where the sludge was generated by anaerobic treatment. The samples of sewage sludge were collected between March 2009 and August 2010, and consisted of raw sludge recently dewatered in a drying bed. The sludge was sanitized by prolonged the alkaline stabilization process with the addition of lime (calcium oxide; total neutralizing power [TNP] 105.1) at 50\% total solids and 30 days of curing. The total content of $\mathrm{Zn}, \mathrm{Cu}$ and $\mathrm{Mn}$ present in the alkaline sewage sludge were determined according to the methodology described in Martins and Reissmann (2007).
For each municipality where the sewage sludge was collected, we also selected the type of agricultural soil most representative of the region. For each soil samples were taken from the $0-20 \mathrm{~cm}$ layer [point known by the use of global position system (GPS)] in area without having added lime for at least five years. The samples were air dried, ground, homogenized, passed through a $2 \mathrm{~mm}$ sieve, and analyzed as to physical and chemical attributes. With the help of location points provided by GPS, soil classes were allocated according to Bhering and Santos (2008). The results of the soil and soil class analyses are shown in Table 1. Detailed information concerning these soils and sludges has been previously reported (Poggere et al., 2012).

Each soil was incubated with increasing rates of alkaline sewage sludge from their respective sector. The incubation assay was employed according to the official methodology described in Brasil (2006). Each soil was incubated with five rates of alkaline sewage sludge $(0,10$, 20,40 , and $80 \mathrm{Mg} \mathrm{ha}^{-1}$ of total solids), with three replications. After 60 days of incubation, soil samples were: collected; air dried; ground; homogenized; passed through a $2 \mathrm{~mm}$ sieve. The $\mathrm{pH}$ of the samples was determined $\left(\mathrm{CaCl}_{2} 0.01 \mathrm{~mol} \mathrm{~L}^{-1}\right.$; soil:solution 1:2.5) (Table 2). To analyze the $\mathrm{Zn}, \mathrm{Cu}$ and $\mathrm{Mn}$ availability, $10 \mathrm{~cm}^{3}$ of soil sample were transferred into glass flasks $(150 \mathrm{ml})$ and then added to $100 \mathrm{~mL}$ of Mehlich-1 (0.05 $\left.\mathrm{mol} \mathrm{L}{ }^{-1} \mathrm{HCl}+0.0125 \mathrm{~mol} \mathrm{~L}^{-1} \mathrm{H}_{2} \mathrm{SO}_{4}\right)$. The flasks remained in a horizontal shaker for 5 minutes and then at rest for one night. The $\mathrm{Zn}, \mathrm{Cu}$ and $\mathrm{Mn}$ concentrations were then determined in the equilibrium solution by atomic absorption spectrometry (Varian, AA240FS).

For each soil, data on $\mathrm{Zn}, \mathrm{Cu}$ and $\mathrm{Mn}$ availability were subjected to analysis of variance (ANOVA), following a completely randomized design with three replications. When ANOVA was significant ( $p<0.05$ ), the data were subjected to regression analysis, choosing the model with the highest coefficient of determination $\left(\mathrm{R}^{2}\right)$ and significance ( $\mathrm{p}<0.05$ or $\mathrm{p}<0.01$ ). To determine the $\mathrm{Zn}, \mathrm{Cu}$ and $\mathrm{Mn}$ recovery efficiency (by Mehlich-1 extraction) as a function of the amount of these elements added to the alkaline sewage sludge application, the following formula was used:

$$
\mathrm{ER}=\frac{((\text { Czero }- \text { Css }) * 2)}{\mathrm{EASS}} * 100
$$

where: ER, element recovery (\%); Czero, element content in soil without alkaline sewage sludge aplication ( $\mathrm{mg} \mathrm{kg}^{-1}$ ); Css, element content in soil with alkaline sewage sludge application $\left(\mathrm{mg} \mathrm{kg}^{-1}\right)$; EASS, element addition with sewage sludge $\left(\mathrm{kg} \mathrm{ha}^{-1}\right)$. 
Table 1: Class and physical and chemical properties of the soil used in the incubation process with alkalized sewage sludge in Paraná, Brazil.

\begin{tabular}{|c|c|c|c|c|c|c|c|c|c|c|c|}
\hline \multirow{2}{*}{ Sector } & \multirow{2}{*}{ Soil class ${ }^{1}$} & Sand $^{3}$ & Silt & Clay & $\mathrm{Al}^{3+}$ & $\mathrm{H}+\mathrm{Al}^{3+}$ & $\mathrm{Ca}^{2+}$ & $\mathrm{Mg}^{2+}$ & \multirow{2}{*}{$\mathrm{K}^{+}$} & \multirow{2}{*}{$\begin{array}{c}P \\
m g ~ d m^{-3}\end{array}$} & \multirow{2}{*}{$\begin{array}{c}\mathrm{OC} \\
\mathrm{g} \mathrm{dm}^{-3}\end{array}$} \\
\hline & & \multicolumn{3}{|c|}{----- g kg$^{-1}$----- } & \multicolumn{4}{|c|}{---- cmolc dm³ } & & & \\
\hline Apucarana & NVef & 58 & 191 & 750 & 0.1 & 5.4 & 4.2 & 2.3 & 0.5 & 2.2 & 24.3 \\
\hline Cascavel & LVdf & 45 & 103 & 850 & 1.3 & 10.5 & 3.6 & 1.2 & 0.3 & 3.6 & 30.7 \\
\hline Campo Mourão & LVdf & 70 & 129 & 800 & 0.9 & 7.2 & 1.5 & 0.8 & 0.2 & 3.4 & 35.1 \\
\hline Francisco Beltrão & LVdf & 31 & 268 & 700 & 5.3 & 17.6 & 2.5 & 1.4 & 0.4 & 3.6 & 19.2 \\
\hline Foz do Iguaçu & NVef & 24 & 326 & 650 & 0.1 & 4.3 & 4.5 & 2.1 & 0.3 & 2.5 & 31.8 \\
\hline Guarapuava & LBd & 35 & 215 & 750 & 1.3 & 12.1 & 1.9 & 1.2 & 0.3 & 2.7 & 38.6 \\
\hline Londrina & LVdf & 40 & 234 & 725 & 0.0 & 4.0 & 2.6 & 1.1 & 0.1 & 2.7 & 15.3 \\
\hline Maringá & NVef & 51 & 198 & 750 & 0.3 & 6.7 & 4.8 & 1.8 & 0.3 & 3.6 & 45.7 \\
\hline Pato Branco & LVdf & 19 & 131 & 850 & 2.9 & 14.1 & 0.5 & 0.1 & 0.1 & 1.3 & 46.9 \\
\hline Pinhais & LBW & 221 & 129 & 650 & 3.7 & 15.8 & 3.1 & 1.6 & 0.1 & 1.3 & 65.4 \\
\hline Toledo & LVdf & 67 & 132 & 800 & 1.5 & 7.8 & 2.0 & 0.9 & 0.5 & 3.7 & 31.8 \\
\hline Cornélio Procópio & NVef & 110 & 439 & 450 & 0.2 & 7.9 & 4.0 & 1.4 & 0.6 & 3.8 & 25.3 \\
\hline Santo Antônio da Platina & LVef & 300 & 274 & 425 & 0.3 & 6.3 & 3.2 & 1.5 & 0.2 & 3.8 & 17.2 \\
\hline Arapongas $^{2}$ & LVd & 701 & 49 & 250 & 1.2 & 7.2 & 1.3 & 0.5 & 0.3 & 4.2 & 23.2 \\
\hline Matinhos & CXbd & 488 & 211 & 300 & 2.3 & 7.8 & 0.1 & 0.2 & 0.1 & 3.2 & 28.5 \\
\hline Ponta Grossa & LV & 646 & 78 & 275 & 0.3 & 4.3 & 1.2 & 0.6 & 0.1 & 2.4 & 13.3 \\
\hline Rio Negro & RRdh & 446 & 328 & 225 & 2.7 & 9.0 & 0.2 & 0.2 & 0.1 & 5.9 & 30.7 \\
\hline Telêmaco Borba & PVAd & 391 & 384 & 225 & 2.4 & 9.7 & 0.5 & 0.1 & 0.1 & 2.2 & 18.2 \\
\hline Paranavaí & $P V d$ & 803 & 47 & 150 & 0.2 & 2.5 & 0.7 & 0.4 & 0.1 & 1.4 & 5.1 \\
\hline Umuarama & LVd & 767 & 33 & 200 & 0.7 & 5.8 & 1.2 & 0.4 & 0.1 & 3.1 & 13.3 \\
\hline
\end{tabular}

${ }^{1}$ Predominant soil type in the mapping unit corresponding to the soil sample collection local, according to Brazilian classification (Bhering; Santos, 2008); LVdf: LATOSSOLO VERMELHO Distroférrico; LBw: LATOSSOLO BRUNO Ácrico; LBd: LATOSSOLO BRUNO Distrófico; Nvef: NITOSSOLO VERMELHO Eutroférrico; RRdh: NEOSSOLO REGOLÍTICO Distro-húmbrico; CXbd = CAMBISSOLO HÁPLICO tb Distrófico; PVAd: ARGISSOLO VERMELHO-AMARELO Distrófico; LVd: LATOSSOLO VERMELHO Distrófico; LV: LATOSSOLO VERMELHO; ${ }^{2}$ Soil collected in the municipality of Maringá, representative of Arapongas sector. ${ }^{3}$ Soil analysis: granulometry by hidrometer method; $\mathrm{Ca}^{2+}$, $\mathrm{Mg}^{2+}, \mathrm{Al}^{3+}\left(\mathrm{extracted} \mathrm{with}^{2}\right.$ $\left.\mathrm{KCl} 1 \mathrm{~mol} \mathrm{~L}^{-1}\right) ; \mathrm{H}^{+} \mathrm{Al}^{3+}$ (Estimated by $\mathrm{pH}-\mathrm{SMP}$ ); organic carbon (OC) (volumetric method by potassium dichromate); $\mathrm{K}^{+}$and $P$ (Mehlich-1 extraction).

\section{RESULTS AND DISCUSSION}

The total $\mathrm{Zn}, \mathrm{Cu}$ and $\mathrm{Mn}$ contents in the alkaline sewage sludge were varied greatly (Table 3 ). All Zn values observed are below the average value of $369 \mathrm{mg}$ $\mathrm{kg}^{-1}$, observed by Bittencourt et al. (2014) for 99 batches of alkaline sewage sludge, intended for agricultural use, from 2007 to 2010 in the metropolitan region of Curitiba. For $\mathrm{Cu}$ values, nine alkaline sewages sludges were higher than the average $96.8 \mathrm{mg} \mathrm{kg}^{-1}$ obtained by Bittencourt et al. (2014). However, both elements were below the total values of $3,176 \mathrm{mg} \mathrm{kg}^{-1}$ for $\mathrm{Zn}$ and 1,019 $\mathrm{mg} \mathrm{kg}^{-1}$ for $\mathrm{Cu}$, obtained by Rangel et al. (2006), who studied sludge coming from the wastewater treatment plant of Barueri, São Paulo, which deals with domestic and industrial sewage.

The values comply with the current legislation for maximum state (Sema 021/09) (Paraná, 2009) and federal levels permitted (Conama 375/06) (Brazil, 2006), with no limitation as to use. These low values are due mainly to low or no presence of industrial dumping in the sewage disposal system, since the policy is to treat industrial sludge before its release into the collection network and Sanepar has restrictive policies regarding reception of industrial wastewater in the sewage system (Paraná, 2013). 
Table 2: $\mathrm{pH}-\mathrm{CaCl}_{2}$ values obtained in soil corresponding to each sector after incubation with increasing rates of the respective alkaline sewage sludge of Paraná State, Brazil.

\begin{tabular}{cccccc}
\hline Sector & \multicolumn{5}{c}{ Sewage sludge $\left(\mathrm{Mg} \mathrm{ha}^{-1}\right)$} \\
\cline { 2 - 6 } & 0 & 10 & 20 & 40 & 80 \\
\hline Apucarana & 5.1 & 5.8 & 6.2 & 6.8 & 7.6 \\
Cascavel & 4.0 & 4.5 & 4.9 & 5.7 & 6.6 \\
Campo Mourão & 4.0 & 5.0 & 5.7 & 6.5 & 7.5 \\
Francisco Beltrão & 4.0 & 4.3 & 4.5 & 5.1 & 6.3 \\
Foz do Iguaçu & 5.1 & 6.0 & 6.7 & 7.6 & 8.1 \\
Guarapuava & 4.4 & 4.5 & 5.2 & 6.2 & 7.3 \\
Londrina & 5.0 & 5.9 & 6.5 & 7.2 & 7.9 \\
Maringá & 4.3 & 5.4 & 6.4 & 7.2 & 7.6 \\
Pato Branco & 3.8 & 4.2 & 4.6 & 5.4 & 6.4 \\
Pinhais & 4.2 & 4.6 & 4.9 & 5.5 & 6.5 \\
Toledo & 3.9 & 4.7 & 5.5 & 6.5 & 7.3 \\
Cornélio Procópio & 4.9 & 6.3 & 7.2 & 7.7 & 8.2 \\
Santo Antônio da Platina & 5.3 & 5.9 & 7.1 & 7.8 & 8.2 \\
Arapongas ${ }^{1}$ & 3.8 & 5.1 & 6.6 & 7.6 & 8.2 \\
Matinhos & 5.6 & 6.3 & 6.8 & 7.2 & 7.7 \\
Ponta Grossa & 4.5 & 6.7 & 7.8 & 8.2 & 8.6 \\
Rio Negro & 5.7 & 6.2 & 6.6 & 7.4 & 8.2 \\
Telêmaco Borba & 3.8 & 4.9 & 5.7 & 7.2 & 7.8 \\
Paranavaí & 4.5 & 7.0 & 7.1 & 8.2 & 8.5 \\
Umuarama & 4.2 & 6.0 & 7.3 & 7.8 & 8.4 \\
Mean & 4.5 & 5.5 & 6.2 & 6.9 & 7.6 \\
\hline Sol & 5.3 & & & \\
\hline
\end{tabular}

${ }^{1}$ Soil collected in the municipality of Maringá, representative of Arapongas sector.

Table 3: Total content and added amounts of $\mathrm{Zn}, \mathrm{Cu}$ and $\mathrm{Mn}$ in 20 alkaline sewage sludges from Paraná state (Brazil) and maximum values established by Sema and Conama regulations.

\begin{tabular}{|c|c|c|c|c|c|c|c|c|c|c|c|c|c|c|c|}
\hline \multirow{2}{*}{ Sector } & \multicolumn{3}{|c|}{$\begin{array}{l}\text { Total content } \\
\left(\mathrm{mg} \mathrm{kg}^{-1}\right)\end{array}$} & \multicolumn{4}{|c|}{$\begin{array}{c}\text { Zn } \\
----\left(k^{-1} h^{-1}\right)---- \\
\end{array}$} & \multicolumn{4}{|c|}{$\begin{array}{c}\mathrm{Cu} \\
----\left(\mathrm{kg} \mathrm{ha}^{-1}\right)---- \\
\end{array}$} & \multicolumn{4}{|c|}{$\begin{array}{c}M n \\
-----\left(k^{-1} h^{-1}\right) \\
\end{array}$} \\
\hline & $\mathrm{Zn}$ & $\mathrm{Cu}$ & $\mathrm{Mn}$ & 10 & 20 & 40 & 80 & 10 & 20 & 40 & 80 & 10 & 20 & 40 & 80 \\
\hline Apucarana & 212 & 36 & 88 & 2.1 & 4.2 & 8.4 & 16.9 & 0.3 & 0.7 & 1.4 & 2.8 & 0.8 & 1.7 & 3.5 & 7.0 \\
\hline Cascavel & 307 & 163 & 105 & 3.0 & 6.1 & 12.2 & 24.5 & 1.6 & 3.2 & 6.5 & 13.0 & 1.0 & 2.1 & 4.2 & 8.4 \\
\hline Campo Mourão & 258 & 79 & 135 & 2.5 & 5.1 & 10.3 & 20.6 & 0.7 & 1.5 & 3.1 & 6.3 & 1.3 & 2.7 & 5.4 & 10.8 \\
\hline Francisco Beltrão & 265 & 70 & 107 & 2.6 & 5.3 & 10.6 & 21.2 & 0.7 & 1.4 & 2.8 & 5.6 & 1.0 & 2.1 & 4.2 & 8.5 \\
\hline Foz do Iguaçu & 51 & 42 & 63 & 0.5 & 1.0 & 2.0 & 4.0 & 0.4 & 0.8 & 1.6 & 3.3 & 0.6 & 1.2 & 2.5 & 5.0 \\
\hline Guarapuava & 226 & 49 & 190 & 2.2 & 4.5 & 9.0 & 18.0 & 0.4 & 0.9 & 1.9 & 3.9 & 1.9 & 3.8 & 7.6 & 15.2 \\
\hline Londrina & 304 & 635 & 148 & 3.0 & 6.0 & 12.1 & 24.3 & 6.3 & 12.7 & 25.4 & 50.8 & 1.4 & 2.9 & 5.9 & 11.8 \\
\hline Maringá & 260 & 189 & 68 & 2.6 & 5.2 & 10.4 & 20.8 & 1.8 & 3.7 & 7.5 & 15.1 & 0.6 & 1.3 & 2.7 & 5.4 \\
\hline
\end{tabular}


Table 3: Continuation.

\begin{tabular}{|c|c|c|c|c|c|c|c|c|c|c|c|c|c|c|c|}
\hline \multirow[t]{2}{*}{ Sector } & \multicolumn{3}{|c|}{$\begin{array}{l}\text { Total content } \\
\left(\mathrm{mg} \mathrm{kg}^{-1}\right)\end{array}$} & \multicolumn{4}{|c|}{$\begin{array}{c}\text { Zn } \\
----\left(k^{k g ~ h a-1}\right) \\
\end{array}$} & \multicolumn{4}{|c|}{$\begin{array}{c}\mathrm{Cu} \\
-----\left(\mathrm{kg} \mathrm{ha}^{-1}\right) \text {----- }\end{array}$} & \multicolumn{4}{|c|}{$\begin{array}{c}M n \\
\text {----- }\left(k^{-1} h^{-1}\right) \text {----- }\end{array}$} \\
\hline & $\mathrm{Zn}$ & $\mathrm{Cu}$ & $\mathrm{Mn}$ & 10 & 20 & 40 & 80 & 10 & 20 & 40 & 80 & 10 & 20 & 40 & 80 \\
\hline Pato Branco & 254 & 101 & 87 & 2.5 & 5.0 & 10.1 & 20.3 & 1.0 & 2.0 & 4.0 & 8.0 & 0.8 & 1.7 & 3.4 & 6.9 \\
\hline Pinhais (CMR) ${ }^{1}$ & 319 & 81 & 117 & 3.1 & 6.3 & 12.7 & 25.5 & 0.8 & 1.6 & 3.2 & 6.4 & 1.1 & 2.3 & 4.6 & 9.3 \\
\hline Toledo & 302 & 126 & 94 & 3.0 & 6.0 & 12.0 & 24.1 & 1.2 & 2.5 & 5.0 & 10.0 & 0.9 & 1.8 & 3.7 & 7.5 \\
\hline Cornélio Procópio & 96 & 108 & 77 & 0.9 & 1.9 & 3.8 & 7.6 & 1.0 & 2.1 & 4.3 & 8.6 & 0.7 & 1.5 & 3.0 & 6.1 \\
\hline Santo Antônio da Platina & 271 & 78 & 127 & 2.7 & 5.4 & 10.8 & 21.6 & 0.7 & 1.5 & 3.1 & 6.2 & 1.2 & 2.5 & 5.0 & 10.1 \\
\hline Arapongas $^{2}$ & 289 & 104 & 107 & 2.8 & 5.7 & 11.5 & 23.1 & 1.0 & 2.0 & 4.1 & 8.3 & 1.0 & 2.1 & 4.2 & 8.5 \\
\hline Matinhos & 288 & 81 & 126 & 2.8 & 5.7 & 11.5 & 23.0 & 0.8 & 1.6 & 3.2 & 6.4 & 1.2 & 2.5 & 5.0 & 10.0 \\
\hline Ponta Grossa & 249 & 48 & 147 & 2.4 & 4.9 & 9.9 & 19.9 & 0.4 & 0.9 & 1.9 & 3.8 & 1.4 & 2.9 & 5.8 & 11.7 \\
\hline Rio Negro & 256 & 53 & 158 & 2.5 & 5.1 & 10.2 & 20.4 & 0.5 & 1.0 & 2.1 & 4.2 & 1.5 & 3.1 & 6.3 & 12.6 \\
\hline Telêmaco Borba & 284 & 68 & 112 & 2.8 & 5.6 & 11.3 & 22.7 & 0.6 & 1.3 & 2.7 & 5.4 & 1.1 & 2.2 & 4.4 & 8.9 \\
\hline Paranavaí & 295 & 238 & 120 & 2.9 & 5.9 & 11.8 & 23.6 & 2.3 & 4.7 & 9.5 & 19.0 & 1.2 & 2.4 & 4.8 & 9.6 \\
\hline Umuarama & 298 & 137 & 103 & 2.9 & 5.9 & 11.9 & 23.8 & 1.3 & 2.7 & 5.4 & 10.9 & 1.0 & 2.0 & 4.1 & 8.2 \\
\hline Sema 021/09 2 & 2,500 & 1,000 & nd & & & & & & & & & & & & \\
\hline Conama 375/06 3 & 2,800 & 1,500 & nd & & & & & & & & & & & & \\
\hline
\end{tabular}

${ }^{1}$ CMR: Curitiba metropolitan region; ${ }^{2}$ Paraná (2009); ${ }^{3}$ Brasil (2006). nd: not available.

The results presented in Table 4 indicate a linear increase of $\mathrm{Zn}$ in 17 of the 20 analyzed soils after application of alkaline sewage sludge. The increase occurred despite an increase in $\mathrm{pH}$, that at a rate of $80 \mathrm{Mg} \mathrm{ha}^{-1}$, promoted $\mathrm{pH}-\mathrm{CaCl}_{2}$ increases to values above 7 in most soils, with an average of 7.6 (Table 2). As a result, the availability of the elements can be affected, with their liberation into the soil solution or with retention/precipitation (Berton \& Nogueira, 2010). Decreased $\mathrm{Zn}$ availability with increasing $\mathrm{pH}$ is well known and, according to Nachtigall, Nogueirol and Alleoni (2009), this fact is related to the transition of exchangeable $\mathrm{Zn}$ to no-exchangeble forms, resulting in precipitation of insoluble forms, such as oxides and organic complex.

However, the acid solution of Mehlich-1 can extract insoluble soil $\mathrm{Zn}$ forms, not satisfactorily discriminating the $\mathrm{pH}$ effect on $\mathrm{Zn}$ availability for plants (Abreu; Lopes; Santos, 2007). This is due to a greater extraction ability of Mehlich-1 compared to other extractors (such as DTPA, for example), a capacity assigned to less weakening of the acid solution in more buffered conditions (Oliveira et al., 1999). This fact indicates an increase in critical $\mathrm{Zn}$ level in soils with high $\mathrm{pH}$ for plant growth. In this direction, Reszel, Reszel and Glowacka (2007) evaluated the influence of sewage sludge and a mixture (sewage sludge, sugar beet residue and ash) on available soil $\mathrm{Zn}$ and
$\mathrm{Cu}$ content $\left(1 \mathrm{~mol} \mathrm{~L}^{-1} \mathrm{HCl}\right.$ extractant $)$ and in corn plants and observed that: in soil, the application of sewage sludge or sludge + waste, increased the levels of these micronutrients; in plants, the two micronutrients decreased. However, it is important to note that the $\mathrm{Zn}$ availability in soil, evaluated by Mehlich-1, shows good correlation with the amount of this nutrient in the plant shoots (Borges; Coutinho, 2004; Sobral et al., 2013). However, Pontoni (2012) found an increase or maintenance of $\mathrm{Zn}$ content in plants in soil amended with alkaline sewage sludge, contrasting with a decrease of $\mathrm{Zn}$ with the isolated application of lime.

Of the three soils that showed no increase in $\mathrm{Zn}$ content after the addition of alkaline sewage sludge (Table 4 ), the only soil in which this result may have a plausible explanation is that from Foz do Iguaçu, as it received sludge with the lowest $\mathrm{Zn}$ level (51 $\mathrm{mg} \mathrm{kg}^{-1}$ ) (Table 3). The sludges from Guarapuava and Santo Antonio da Platina showed levels of 226 and $271 \mathrm{mg} \mathrm{kg}^{-1}$. The lack of change in $\mathrm{Zn}$ availability with the addition of alkaline sewage sludge may be due to the $\mathrm{Zn}$ release (which may have been low) from the sludge itself and/or transformation of $\mathrm{Zn}$ into forms that the extractant was unable to extract in solid phase. Thus, for a minority of cases, the alkaline sewage sludge will bring no $\mathrm{Zn}$ availability benefits, and more studies are needed to identify the factors related to the $\mathrm{Zn}$ increase absence. 
Table 4: Available Zn in soils of Paraná state (Brazil) as a function of increasing sludge rates from their respective sector and the best regression equations.

\begin{tabular}{|c|c|c|c|c|c|c|c|c|c|c|}
\hline \multirow{2}{*}{$\mathrm{TC}^{1}$} & \multirow{2}{*}{ Sector } & \multicolumn{5}{|c|}{ Alkaline sewage sludge $\left(\mathrm{Mg} \mathrm{ha}^{-1}\right)$} & \multirow{2}{*}{ Sig } & \multirow{2}{*}{ Equation } & \multirow{2}{*}{$\mathrm{R}^{2}$} & \multirow{2}{*}{ CV } \\
\hline & & 0 & 10 & 20 & 40 & 80 & & & & \\
\hline \multicolumn{10}{|c|}{----- Available Zn $\left(\mathrm{mg} \mathrm{dm}^{-3}\right)$} & $\%$ \\
\hline \multirow{10}{*}{$\begin{array}{l}\text { Very } \\
\text { clayey }\end{array}$} & Apucarana & $4.7 \S$ & 6.4 & 7.7 & 9.6 & $15.5 \S$ & ** & $y=4.869+0.131 x$ & 0.99 & 3.2 \\
\hline & Cascavel & $3.5 \S$ & 5.2 & 7.2 & 11.3 & $17.3 \S$ & ** & $y=3.673+0.174 x$ & 0.99 & 4.8 \\
\hline & Campo Mourão & $1.6 /$ & 1.4 & 1.6 & 2.3 & $4.3 \S$ & ** & $y=1.106+0.038 x$ & 0.94 & 10.3 \\
\hline & Francisco Beltrão & $1.2 \dagger$ & 1.4 & 1.9 & 2.9 & $5.1 \S$ & ** & $y=0.976+0.051 x$ & 0.99 & 11.3 \\
\hline & Foz do Iguaçu & $3.0 \S$ & 2.6 & 2.9 & 3.2 & $2.9 \S$ & ns & --- & --- & 14.1 \\
\hline & Guarapuava & $2.9 \S$ & 4.0 & 3.0 & 3.1 & $5.1 \S$ & ns & --- & --- & 3.1 \\
\hline & Londrina & $1.6 /$ & 3.2 & 6.0 & 10.1 & $15.6 \S$ & ** & $y=1.960+0.178 x$ & 0.98 & 4.5 \\
\hline & Maringá & $4.1 \S$ & 4.2 & 5.8 & 8.8 & $10.3 \S$ & ** & $y=4.094+0.085 x$ & 0.91 & 5.8 \\
\hline & Pato Branco & $1.2 \dagger$ & 3.4 & 2.3 & 3.1 & $5.9 \S$ & ** & $y=1.687+0.050 x$ & 0.81 & 33.6 \\
\hline & Pinhais $(\mathrm{CMR})^{2}$ & $3.6 \S$ & 4.6 & 6.0 & 4.8 & $6.8 \S$ & $\star$ & $y=4.179+0.032 x$ & 0.67 & 27.9 \\
\hline \multirow{3}{*}{ Clayey } & Toledo & $1.7 /$ & 3.5 & 5.6 & 8.8 & $14.5 \S$ & ** & $y=2.035+0.159 x$ & 0.99 & 5.5 \\
\hline & Cornélio Procópio & $3.5 \S$ & 3.8 & 4.2 & 5.4 & $6.9 \S$ & ** & $0.0435 x+3.455$ & 0.99 & 8.3 \\
\hline & St Ant da Platina & $2.5 /$ & 3.0 & 8.5 & 5.5 & $3.5 \S$ & ns & --- & --- & 6.4 \\
\hline \multirow{7}{*}{$\begin{array}{l}\text { Medium } \\
\text { texture }\end{array}$} & Arapongas & $3.6 \S$ & 3.4 & 5.6 & 11.0 & $18.3 \S$ & ** & $y=2.447+0.197 x$ & 0.97 & 10.8 \\
\hline & Matinhos & $1.7 /$ & 2.3 & 3.7 & 5.0 & $6.4 \S$ & $* *$ & $y=2.080+0.058 x$ & 0.93 & 14.5 \\
\hline & Ponta Grossa & $2.4 \S$ & 2.8 & 3.5 & 5.8 & $7.6 \S$ & ** & $y=2.381+0.068 x$ & 0.97 & 4.1 \\
\hline & Rio Negro & $1.5 \dagger$ & 2.4 & 2.5 & 2.7 & $6.2 \S$ & $* *$ & $y=1.400+0.055 x$ & 0.91 & 23.7 \\
\hline & Telêmaco Borba & $1.2 \dagger$ & 3.3 & 2.9 & 6.3 & $10.4 \S$ & ** & $y=1.440+0.113 x$ & 0.97 & 17.8 \\
\hline & Paranavaí & $0.7 \ddagger$ & 6.6 & 9.5 & 12.5 & $17.8 \S$ & ** & $y=3.676+0.191 x$ & 0.89 & 9.9 \\
\hline & Umuarama & $1.8 /$ & 3.3 & 5.5 & 8.0 & $12.3 \S$ & ** & $y=2.276+0.130 x$ & 0.98 & 5.3 \\
\hline
\end{tabular}

${ }^{1} \mathrm{TC}=$ textural class; ${ }^{2} \mathrm{CMR}=$ Curitiba metropolitan region; Costa and Oliveira (1998), $\S=$ high available $\mathrm{Zn}$ in soil; / = good available $\mathrm{Zn}$ in soil; $\dagger=$ mean available $\mathrm{Zn}$ in soil; $¥=$ low available $\mathrm{Zn}$ in soil; $\mathrm{ns}=$ not significant; * and **significant at 5 and $1 \%$, respectively; $c v=$ coeficient of variation.

The magnitude of $\mathrm{Zn}$ increase due to alkaline sewage sludge varied between soil and sludge. Alkaline sewage sludge from Pinhais was that with the highest total $\mathrm{Zn}$ content (319 $\mathrm{mg} \mathrm{kg}^{-1}$ ), but the increase in available $\mathrm{Zn}$ in the soil was $0.032 \mathrm{mg} \mathrm{Mg}^{-1}$ of sludge, reaching values of 1.8 times higher at the maximum rate $\left(80 \mathrm{Mg} \mathrm{ha}^{-1}\right)$ in comparison to soil without sludge application. For Cascavel, Toledo and Londrina, which showed total $\mathrm{Zn}$ content in sludge similar to Pinhais, increases in the $\mathrm{Zn}$ availability were $4.9 ; 8.5$ and 9.7 fold, following the additions of $0.174 ; 0.154$ and $0.178 \mathrm{mg} \mathrm{Mg}^{-1}$ of sludge, respectively. This result was probably due to higher organic carbon $\left(65 \mathrm{~g} \mathrm{dm}^{-3}\right)$ present in Pinhais soil. According to Alloway (1995), the humic substances present a high degree of selectivity for micronutrients; in this case, greater affinity for $\mathrm{Cu}$ and lower for $\mathrm{Zn}$, but forming the inner sphere complexes with both elements. Studies with $\mathrm{Zn}$ fractionation in soil have reported that with increasing $\mathrm{pH}$, exchangeable $\mathrm{Zn}$ decreases, but $\mathrm{Zn}$ associated with organic fraction and mineral fraction of the soil present increases (Melo et al., 2008; Torri; Lavado, 2008). In all soils, $Z n$ available content reached appropriate or high levels from the second rate applied (Table 4), but did not reach levels above $30 \mathrm{mg} \mathrm{dm}^{-3}$, considered excessive (Costa; Oliveira, 1998). However, the total amount of $\mathrm{Zn}$ applied to the maximum sludge rate $\left(80 \mathrm{Mg} \mathrm{ha}^{-1} \mathrm{x} \mathrm{Zn}\right.$ content in the sludge), ranged from $4.1 \mathrm{~kg} \mathrm{ha}^{-1}$ (Foz do Iguaçu) 
to $25.5 \mathrm{~kg} \mathrm{ha}^{-1}$ (Pinhais), being higher than those usually recommended. According to Raij et al. (1996), for São Paulo state, the recommended $\mathrm{Zn}$ rates range from 1 to $6 \mathrm{~kg} \mathrm{ha}^{-1}$ for different crops. The Commission of Chemistry and Soil Fertility (CQFS-RS/SC, 2004), cites that micronutrient deficiency is unlikely in Rio Grande do Sul and Santa Catarina states. However, Motta et al. (2007) report that the $\mathrm{Zn}$ appears frequently at critical levels in Paraná soils.

In general, the $\mathrm{Zn}$ recovery by the Mehlich-1 extractor ranged from $-154 \%$ to $399 \%$ (Figure 1), and in only three soils were negative recovery values observed (Campo Mourão, Foz do Iguaçu and Arapongas). Negative values indicate a decrease in soil native $\mathrm{Zn}$ with alkaline sewage sludge, overlaps the $\mathrm{Zn}$ applied. On the other hand, values above $100 \%$ suggest that the alkaline sewage sludge, besides making $\mathrm{Zn}$ available, intensified the release $\mathrm{Zn}$ from low availability forms to available forms.

In very clayey and clayey soils $\mathrm{Zn}$ recovery for the highest rate $\left(80 \mathrm{Mg} \mathrm{ha}^{-1}\right)$ ranged from -5 to $127 \%$ (Figure 1$)$. The highest values were observed in Apucarana (127\%), Londrina (115\%), Cascavel (112\%) and Toledo (106\%) soils, that received sludge with $\mathrm{Zn}$ levels above $212 \mathrm{mg}$ $\mathrm{kg}^{-1}$ (Table 3). Despite the high clay content and probably higher oxide contents, which could promote high adsorption specific Zn (Birth; Supplies, 2004; Motta et al., 2007), the results for the four above-mentioned soils (higher recovery $\mathrm{Zn}$ ) indicate that the $\mathrm{Zn}$ availability varied with the soil attributes and nutrient content of each sludge. These results emphasize that in this study, the effect of soil $\mathrm{pH}$, after alkaline sewage sludge application, had little influence on the availability of $\mathrm{Zn}$ by the Mehlich-1 extractor.

The medium texture soils presented $\mathrm{Zn}$ recovery varying between 41 and $144 \%$ in application of $80 \mathrm{Mg} \mathrm{ha}^{-1}$ (Figure 1), and the Paranavaí soil presented the higher rate $(144 \%)$ of $Z n$ recovery. However, it is noteworthy that this soil has a clay content of $150 \mathrm{~g} \mathrm{~kg}^{-1}$, near the lower limit for sandy soils, and in soils like this, the maximum application rate of alkaline sewage sludge (Poggere et al., 2012) is much less than the highest rate $\left(80 \mathrm{Mg} \mathrm{ha}^{-1}\right)$ used in this study. Similar results was observed in Arapongas and Umuarama soils, with clay contents of 250 and $200 \mathrm{~g} \mathrm{~kg}^{-1}$, and 127 and $88 \%$ recovery rates, respectively, for the rate of $80 \mathrm{Mg} \mathrm{ha}^{-1}$. In this condition, due to the smaller amount of clay, $\mathrm{Zn}$ released from sludge probably had low adsorption on the soil solid phase (Abreu; Lopes; Santos, 2007), allowing high recovery values.

Similar to that observed for $\mathrm{Zn}, \mathrm{Cu}$ availability after addition of alkaline sewage sludge varied depending on the soil (Table 5). But unlike $\mathrm{Zn}$, responses ranged from a $\mathrm{Cu}$ decrease to increase. This can be explained by the lower $\mathrm{Cu}$ content in the sludge, compared to Zn, except for Londrina sludge. A direct relationship between sludge rate and available $\mathrm{Cu}$ was observed; with linear and quadratic equations for 9 soils and 1 soil. However, an inverse relationship was observed with linear and quadratic equations for 8 soils and 1 soil. That is, only one soil did not present a change resulting from the alkaline sewage sludge application.

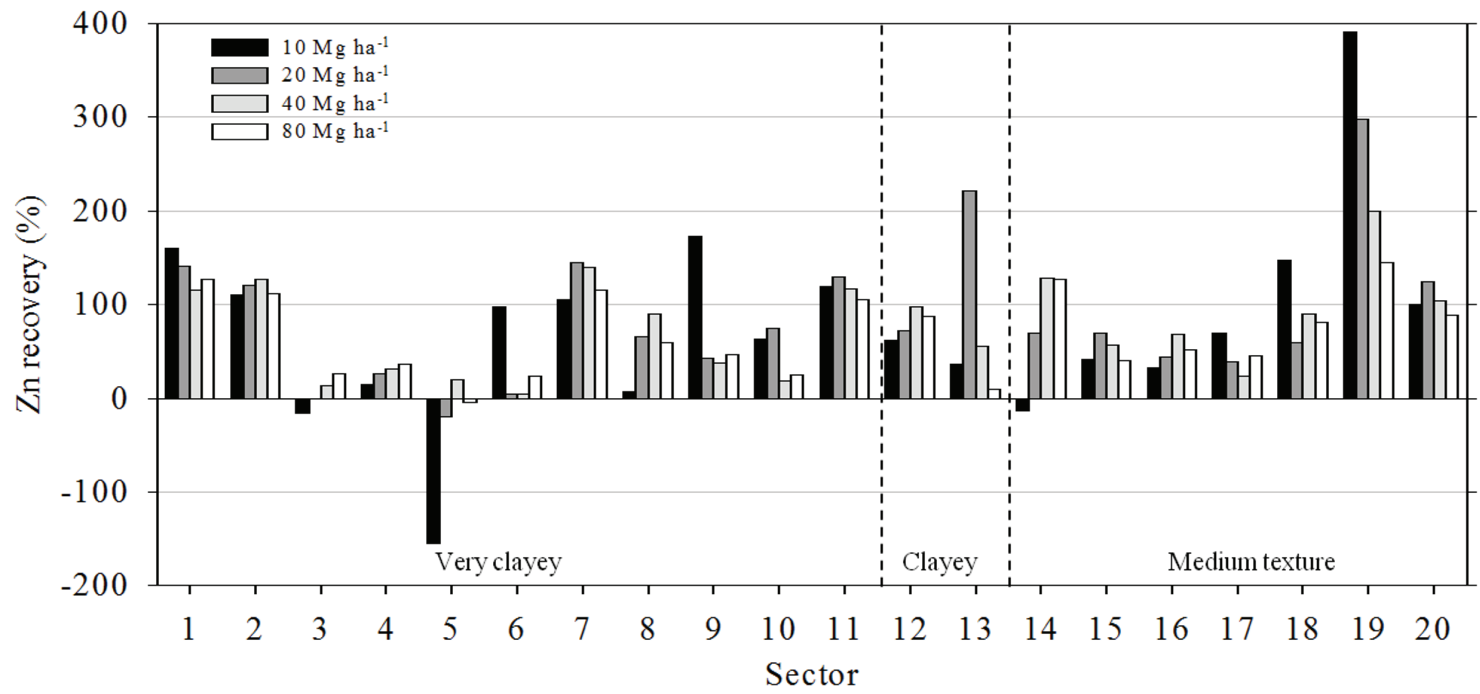

Figure 1: Zinc recovery (\%) (Mehlich-1 extractor) from soils treated with alkaline sewage sludge from Paraná, Brazil. Sector: 1 - Apucarana; 2 - Cascavel; 3 - Campo Mourão; 4 - Francisco Beltrão; 5 - Foz do Iguaçu; 6 - Guarapuava; 7 Londrina; 8 - Maringá; 9 - Pato Branco; 10 - Pinhais; 11 - Toledo; 12 - Cornélio Procópio; 13 - Santo Antônio da Platina; 14 - Arapongas; 15 - Matinhos; 16 - Ponta Grossa; 17 - Rio Negro; 18 - Telêmaco Borba; 19 - Paranavaí; 20 - Umuarama. 
Table 5: Available Cu in soils of Paraná state (Brazil) as a function of increasing sludge rates from their respective sector and the best regression equations.

\begin{tabular}{|c|c|c|c|c|c|c|c|c|c|c|}
\hline \multirow{2}{*}{$\mathrm{TC}^{1}$} & \multirow{2}{*}{ Sector } & \multicolumn{5}{|c|}{ Alkaline sewage sludge $\left(\mathrm{Mg} \mathrm{ha}^{-1}\right)$} & \multirow{2}{*}{ Sig } & \multirow{2}{*}{ Equation } & \multirow{2}{*}{$\mathrm{R}^{2}$} & \multirow{2}{*}{$\mathrm{CV}$} \\
\hline & & 0 & 10 & 20 & 40 & 80 & & & & \\
\hline \multirow{11}{*}{ Very clayey } & & \multicolumn{5}{|c|}{------ Available Cu (mg dm³) ------ } & & & & $\%$ \\
\hline & Apucarana & $10.6 ¥$ & 8.9 & 8.9 & 8.7 & $6.6 \S$ & * & $y=10.002-0.041 x$ & 0.86 & 5.2 \\
\hline & Cascavel & $7.6 \S$ & 8.2 & 8.4 & 8.5 & $9.1 ¥$ & $* *$ & $y=7.890+0.016 x$ & 0.85 & 3.5 \\
\hline & Campo Mourão & $5.9 \S$ & 5.3 & 4.9 & 4.5 & $4.4 \S$ & ** & $y=5.512-0.017 x$ & 0.76 & 4.2 \\
\hline & Francisco Beltrão & $12.4 ¥$ & 11.0 & 10.1 & 9.9 & $11.3 ¥$ & ** & $y=12.2-0.116 x+0.001 x^{2}$ & 0.94 & 5.3 \\
\hline & Foz do Iguaçu & $10.5 ¥$ & 8.6 & 8.5 & 8.3 & $7.5 \S$ & ** & $y=9.536-0.029 x$ & 0.67 & 5.1 \\
\hline & Guarapuava & $2.8 \S$ & 2.8 & 2.6 & 2.2 & $2.1 \S$ & $* *$ & $y=2.800-0.010 x$ & 0.89 & 22.8 \\
\hline & Londrina & $13.0 ¥$ & 16.1 & 18.6 & 21.1 & $20.7 ¥$ & ** & $y=15.317+0.086 x$ & 0.65 & 5.6 \\
\hline & Maringá & $3.5 \S$ & 2.9 & 3.2 & 3.0 & $1.8 /$ & $* *$ & $y=3.437-0.018 x$ & 0.83 & 6.1 \\
\hline & Pato Branco & $3.8 \S$ & 3.6 & 3.7 & 3.3 & $3.1 /$ & $* *$ & $y=3.747-0.008 x$ & 0.81 & 33.6 \\
\hline & Pinhais (RMC)2 & $2.9 \S$ & 2.7 & 2.5 & 2.5 & $1.4 \dagger$ & $* *$ & $y=2.905-0.017 x$ & 0.91 & 17.9 \\
\hline \multirow{3}{*}{ Clayey } & Toledo & $8.0 ¥$ & 8.3 & 8.4 & 8.7 & $8.1 ¥$ & ns & --- & --- & 5.6 \\
\hline & Cornélio Procópio & $9.3 ¥$ & 9.6 & 8.9 & 8.4 & $6.8 \S$ & $* *$ & $y=9.631-0.034 x$ & 0.96 & 3.7 \\
\hline & St. Ant. da Platina & $8.9 ¥$ & 9.5 & 11.8 & 11.2 & $9.9 ¥$ & $* *$ & $y=8.9+0.125 x-0.001 x^{2}$ & 0.75 & 5.8 \\
\hline \multirow{7}{*}{$\begin{array}{l}\text { Medium } \\
\text { texture }\end{array}$} & Arapongas & $1.0 \dagger$ & 1.2 & 1.3 & 1.6 & $1.6 /$ & $* *$ & $y=1.089+0.007 x$ & 0.77 & 13.4 \\
\hline & Matinhos & $2.2 \S$ & 2.1 & 2.3 & 2.6 & $2.7 \S$ & ** & $y=2.158+0.007 x$ & 0.84 & 8.1 \\
\hline & Ponta Grossa & $1.9 /$ & 1.9 & 2.1 & 2.2 & $2.2 \S$ & ** & $y=1.931+0.004 x$ & 0.72 & 11.2 \\
\hline & Rio Negro & $1.7 /$ & 1.8 & 2.0 & 1.9 & $2.1 \S$ & $* *$ & $y=1.775+0.004 x$ & 0.86 & 3.6 \\
\hline & Telêmaco Borba & $0.9 \dagger$ & 1.4 & 1.3 & 1.5 & $1.8 /$ & ** & $y=1.084+0.010 x$ & 0.82 & 6.2 \\
\hline & Paranavaí & $1.2 \dagger$ & 2.0 & 2.9 & 4.7 & $7.4 \S$ & ** & $y=1.289+0.077 x$ & 0.99 & 14.7 \\
\hline & Umuarama & $2.1 \S$ & 2.3 & 2.7 & 2.9 & $3.1 \S$ & $* *$ & $y=2.295+0.011 x$ & 0.81 & 4.9 \\
\hline
\end{tabular}

${ }^{1} \mathrm{TC}=$ textural class; ${ }^{2} \mathrm{CMR}=$ Curitiba metropolitan region; Costa and Oliveira (1998), $¥=$ very high available Cu in soil; $\S=$ high available $\mathrm{Cu}$ in soil; / = good available $\mathrm{Cu}$ in soil; $\dagger=$ mean available $\mathrm{Cu}$ in soil; $\ddagger=$ low available $\mathrm{Cu}$ in soil; ns = not significant; * and **significant at 5 e $1 \%$, respectively; cv = coeficient of variation.

The $\mathrm{Cu}$ availability decreases with the use of alkaline sewage sludge were observed in 9 of 13 clayey and very clayey soils (Table 5). In addition to the higher clay content, this group of soils showed high organic carbon content. Thus, smaller increases in $\mathrm{Cu}$ compared to $\mathrm{Zn}$ are evident, as well as the importance of the texture in the $\mathrm{Cu}$ response due to sludge.

The lowest Mehlich-1 $\mathrm{Cu}$ extraction ability, compared to $\mathrm{Zn}$ was observed; and is possibly related to at least three reasons: 1) $\mathrm{Cu}$ has a lower hydrolysis constant than $\mathrm{Zn}$, which is related to the formation of complexes with higher binding energy (Sparks, 2003); 2) Cu has a higher electronegativity than $\mathrm{Zn}$, being more strongly bound by the mineral constituents of the soil (Arias et al, 2006); 3) $\mathrm{Cu}$ has a higher affinity for organic matter in comparison to $\mathrm{Zn}$ (Souza et al., 2012).

Corroborating the $\mathrm{Cu}$ availability decrease results, Fan et al. (2011) observed reduction in exchangeable content (readily available) and increase in content in the oxides and the residual fraction after application of alkaline sludge. The authors explain the reduction of $\mathrm{Cu}$ exchangeable by its precipitation in the form of carbonates. On the other hand, the increase in $\mathrm{Cu}$ availability in soil with very clayey texture (Table 5) can be justified by the high $\mathrm{Cu}$ content in Londrina sludge (635 mg kg-1), well above the levels the other sludges (mean $97 \mathrm{mg} \mathrm{kg}^{-1}$, range: $36-238 \mathrm{mg} \mathrm{kg}^{-1}$ ) (Table 3). For Cascavel soil this result was not expected, which has 
a quarter of Londrina sludge content and high carbon $\left(30.7 \mathrm{~g} \mathrm{dm}^{-3}\right)$ and clay content $\left(850 \mathrm{~g} \mathrm{~kg}^{-1}\right)$, which would provide a high adsorption capacity to the soil.

Of the other soils that showed an increase in the $\mathrm{Cu}$ availability in response to the sludge addition, all have a medium texture (300-150 $\left.\mathrm{g} \mathrm{kg}^{-1}\right)$. As a result, buffering capacity of these soils is low, which reduces the capacity of the solid phase to adsorb $\mathrm{Cu}$ added via sludge. Another consequence of the low buffering capacity of medium texture soils is that there was no effect on the extraction capacity of the Mehlich-1, even with increasing $\mathrm{pH}$ values above 7 in the higher sludge rate. This effect is evident when one carefully examines the soil characteristics. The increase in the available $\mathrm{Cu}$ in Paranavaí soil at a high sludge rate $\left(80 \mathrm{Mg} \mathrm{ha}^{-1}\right)$ was $6.1 \mathrm{fold}$, in comparison to the soil that did not received sludge, while in the remaining medium texture soils, increases were between 1.1 and 2.0 fold. This result is a consequence of the low clay $(150 \mathrm{~g}$ $\left.\mathrm{kg}^{-1}\right)$ and organic carbon content $\left(5.1 \mathrm{~g} \mathrm{dm}^{-3}\right)$ of Paranavaí soil and higher $\mathrm{Cu}$ content in the sludge $\left(137 \mathrm{mg} \mathrm{kg}^{-1}\right)$, compared to sludge applied to medium texture soils.

In general, the $\mathrm{Cu}$ recovery by Mehlich- 1 extractor was negative for seven very clayey soils (Figure 2). There was $\mathrm{Cu}$ retention in these soils and the addition of sludge acts more like a drain than as a source, due to the influence of the $\mathrm{pH}$ increase on the increase of the $\mathrm{Cu}$ adsorption capacity for the mineral or organic soil fraction (Arias et al., 2006; Souza et al., 2012). But, the $\mathrm{Cu}$ recovery was positive for two very clayey, one clayey and six medium texture soils (Figure 2). Thus, besides the soil ability to adsorb $\mathrm{Cu}$, other factors affect the recovery (e.g., amount of $\mathrm{Cu}$ added via sludge, sludge decomposition and mineralization of $\mathrm{Cu}$ ).

The amount of total $\mathrm{Cu}$ applied per hectare to the soil with the sludge at the largest sludge rate $\left(80 \mathrm{Mg} \mathrm{ha}^{-1} \times \mathrm{Cu}\right.$ content in the sludge), ranged from 3 to $51 \mathrm{~kg} \mathrm{ha}^{-1}$. These $\mathrm{Cu}$ values are higher than generally recommended. According to Raij et al. (1996), for São Paulo state, the recommended $\mathrm{Cu}$ rates range from 1 to $5 \mathrm{~kg} \mathrm{ha}^{-1}$ for different cultures. But, $\mathrm{Cu}$ and $\mathrm{Zn}$ have long residual effect in the soil, according to Fan et al. (2011), this residual effect is due to the prevalence of specific adsorption to soil mineral and organic colloids. Thus, monitoring $\mathrm{Cu}$ content in the soil is necessary to avoid high sludge applications rates causing $\mathrm{Cu}$ toxicity in plants, especially in soils with low buffering capacity.

Unlike $\mathrm{Zn}$, the Mn availability after the addition of alkaline sewage sludge decreased in 15 soils, increased in two soils and did not change in three (Table 6). The amount of $\mathrm{Mn}$ applied, generally, is near that applied to $\mathrm{Cu}$, which indicates that not only the amount should be considered. Thus, decreasing levels of available $\mathrm{Mn}$ in these soils is directly linked to increased sensitivity of the element to the $\mathrm{pH}$ change (Abreu; Lopes; Santos, 2007). With the increase of the soil $\mathrm{pH}$, the $\mathrm{Mn}^{2+}$ cationic form is converted into manganic oxides (Hue; May, 2002) or strongly bound to organic matter (Moreira et al., 2016; Nachtigall; Nogueirol; Alleonni, 2009).

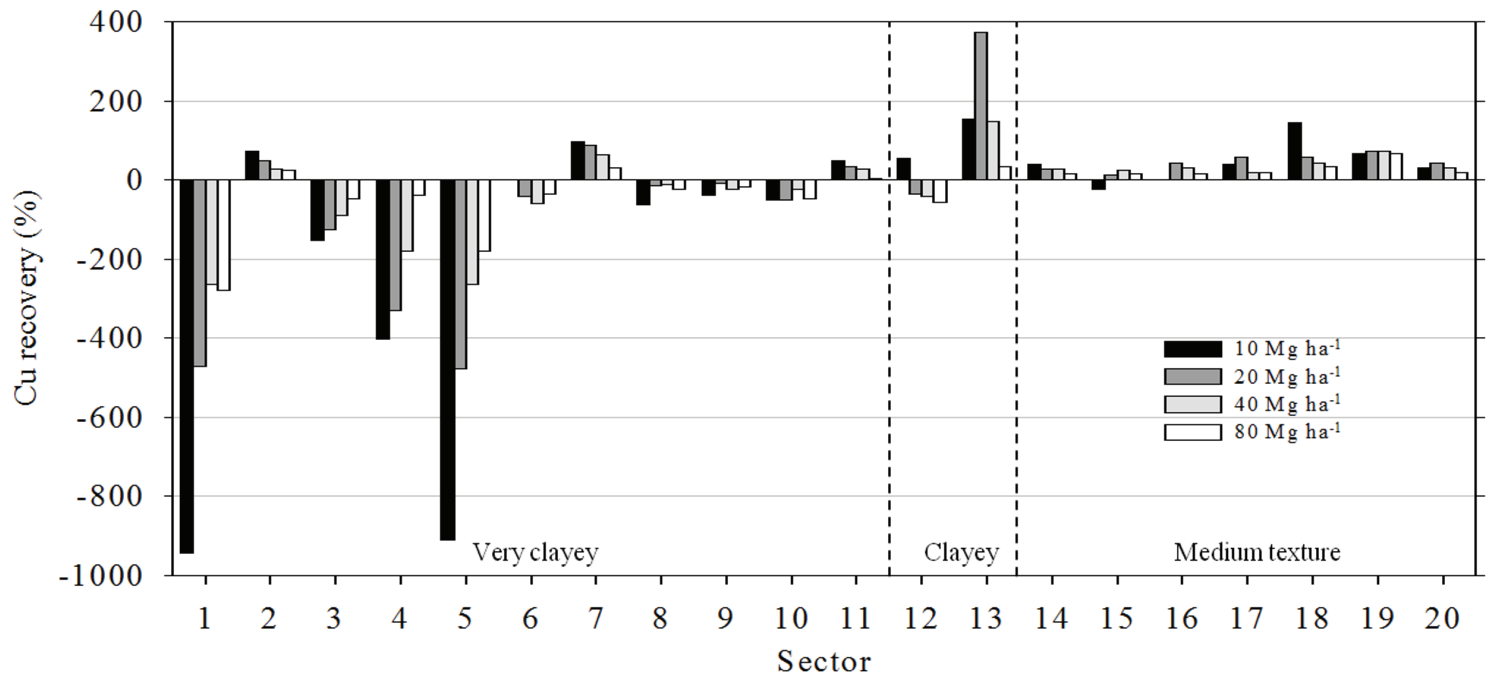

Figure 2: Copper recovery (\%) (Mehlich-1 extractor) from soils treated with alkaline sewage sludge from Paraná, Brazil. Sector: 1 - Apucarana; 2 - Cascavel; 3 - Campo Mourão; 4 - Francisco Beltrão; 5 - Foz do Iguaçu; 6 - Guarapuava; 7 Londrina; 8 - Maringá; 9 - Pato Branco; 10 - Pinhais; 11 - Toledo; 12 - Cornélio Procópio; 13 - Santo Antônio da Platina; 14 - Arapongas; 15 - Matinhos; 16 - Ponta Grossa; 17 - Rio Negro; 18 - Telêmaco Borba; 19 - Paranavaí; 20 - Umuarama. 
On the other hand, Matinhos and Telêmaco Borba, who obtained an increase in Mn availability, showed behavior contrary to other soils with similar clay and organic matter content. Borges and Coutinho (2004) applied sewage sludge with and without lime in two soils, and observed an increase in available $\mathrm{Mn}$ extracted by Mehlich-1. Abreu et al. (2004) point out that higher values of Mn extracted by Mehlich-1 solution (acidic solution) and Mehlich-3 (mixed solution) may be due to greater capacity for solubilizing $\mathrm{Mn}$ in some soils, particularly when linked to iron oxides.

The Mn recovery by Mehlich-1 extractor was negative in 18 soils, with very low levels, reaching $-8571 \%$ (Foz do Iguaçu soil, at a rate of $10 \mathrm{Mg} \mathrm{ha}^{-1}$ ) (Figure 3).
The extremely low recovery values demonstrate how $\mathrm{Mn}$ is influenced by $\mathrm{pH}$ values and $\mathrm{Mn}$ content in sewage sludge. In practical terms, the decrease in Mn may be a positive aspect, since it is the second most likely element to cause toxicity in acid soils (Millaleo et al., 2010). Therefore, the $\mathrm{pH}$ increase and decrease in Mn availability can mean its toxicity decrease and a benefit to plants. Corroborating the results of this study, Pontoni (2012) found a large decrease in $\mathrm{Mn}$ content in leaf tissue as a result of the alkaline sewage sludge application in soil. However, we found that despite the decrease in the Mn availability in most soils, there was virtually no change in the interpretation of $\mathrm{Mn}$ level in the soil (Table 6).

Table 6: Available Mn in soils of Paraná state (Brazil) as a function of increasing sludge rates from their respective sector and the best regression equations.

\begin{tabular}{|c|c|c|c|c|c|c|c|c|c|c|}
\hline \multirow{2}{*}{$\mathrm{TC}^{1}$} & \multirow{2}{*}{ Sector } & \multicolumn{5}{|c|}{ Alkaline sewage sludge (Mg ha-1) } & \multirow{2}{*}{ Sig } & \multirow{2}{*}{ Equation } & \multirow{2}{*}{$\mathrm{R}^{2}$} & \multirow{2}{*}{ CV } \\
\hline & & 0 & 10 & 20 & 40 & 80 & & & & \\
\hline \multirow{11}{*}{ Very clayey } & & \multicolumn{5}{|c|}{----- Available $\mathrm{Mn}\left(\mathrm{mg} \mathrm{dm}^{-3}\right)$------ } & & & & $\%$ \\
\hline & Apucarana & $195 ¥$ & 179 & 174 & 153 & $160 ¥$ & ** & $y=89.434-0.182 x$ & 0.65 & 7.8 \\
\hline & Cascavel & $149 \S$ & 142 & 136 & 134 & $137 \S$ & ns & --- & --- & 6.3 \\
\hline & Campo Mourão & $42 \S$ & 36 & 31 & 27 & $26 \S$ & ** & $y=38.308-0.185 x$ & 0.72 & 10.9 \\
\hline & Francisco Beltrão & $104 \S$ & 93 & 90 & 79 & $78 \S$ & $\star \star$ & $y=98.439-0.303 x$ & 0.76 & 8.1 \\
\hline & Foz do Iguaçu & $192 ¥$ & 165 & 148 & 133 & $135 \S$ & ** & $y=173.530-0.609 x$ & 0.62 & 4.5 \\
\hline & Guarapuava & $67 \S$ & 59 & 52 & 43 & $44 \S$ & ** & $y=61.468-0.264 x$ & 0.69 & 8.1 \\
\hline & Londrina & $221 ¥$ & 208 & 200 & 192 & $165 ¥$ & ** & $y=217.200-0.658 x$ & 0.98 & 3.8 \\
\hline & Maringá & $186 ¥$ & 160 & 155 & 123 & $83 \S$ & ** & $y=178.820-1.228 x$ & 0.98 & 6.2 \\
\hline & Pato Branco & $43 \S$ & 32 & 31 & 32 & $28 \S$ & ** & $y=37.593-0.133 x$ & 0.53 & 10.6 \\
\hline & Pinhais (RMC) ${ }^{2}$ & $35 \S$ & 23 & 13 & 11 & $9 /$ & ** & $Y=26.573-0.267 x$ & 0.60 & 12.0 \\
\hline \multirow{3}{*}{ Clayey } & Toledo & $95 \S$ & 83 & 83 & 81 & $76 \S$ & ** & $y=89.434-0.182 x$ & 0.65 & 7.9 \\
\hline & Cornélio Procópio & $188 ¥$ & 176 & 159 & 147 & $167 ¥$ & ** & $y=175.030-0.239 x$ & 0.23 & 4.7 \\
\hline & St Ant da Platina & $182 ¥$ & 180 & 160 & 169 & $166 ¥$ & * & $y=176.530-0.158 x$ & 0.31 & 5.5 \\
\hline \multirow{7}{*}{$\begin{array}{l}\text { Medium } \\
\text { texture }\end{array}$} & Arapongas & $47 \S$ & 39 & 41 & 36 & $39 \S$ & * & $y=43.158-0.073 x$ & 0.34 & 9.7 \\
\hline & Matinhos & $1.7 \ddagger$ & 2.0 & 3.2 & 3.4 & $3.5 \ddagger$ & $* \star$ & $y=2.145+0.021 x$ & 0.64 & 19.5 \\
\hline & Ponta Grossa & $12 /$ & 10 & 10 & 10 & $11 /$ & ** & $y=11.6-0.079 x+0.001 x^{2}$ & 0.68 & 7.8 \\
\hline & Rio Negro & $11 /$ & 10 & 10 & 9.9 & $11 /$ & * & $y=11.5-0.081 x+0.001 x^{2}$ & 0.40 & 8.7 \\
\hline & Telêmaco Borba & $11 /$ & 13 & 14 & 17 & $17 \S$ & ** & $y=12.361+0.082 x$ & 0.82 & 9.3 \\
\hline & Paranavaí & $66 \S$ & 48 & 54 & 62 & $67 \S$ & * & $y=59.6-0.249 x+0.004 x^{2}$ & 0.38 & 12.3 \\
\hline & Umuarama & $87 \S$ & 65 & 74 & 54 & $50 \S$ & * & $y=78.721-0.408 x$ & 0.70 & 27.0 \\
\hline
\end{tabular}

${ }^{1} \mathrm{TC}=$ textural class; ${ }^{2} \mathrm{CMR}=$ Curitiba metropolitan region; Costa and Oliveira (1998), $¥=$ very high available Mn in soil; $\S=$ high available $\mathrm{Mn}$ in soil; / = good available $\mathrm{Mn}$ in soil; $†$ = mean available $\mathrm{Mn}$ in soil; $¥=$ low available $\mathrm{Mn}$ in soil; $\mathrm{ns}=$ not significant; * and **significant at 5 e $1 \%$, respectively; $c v=$ coeficient of variation. 


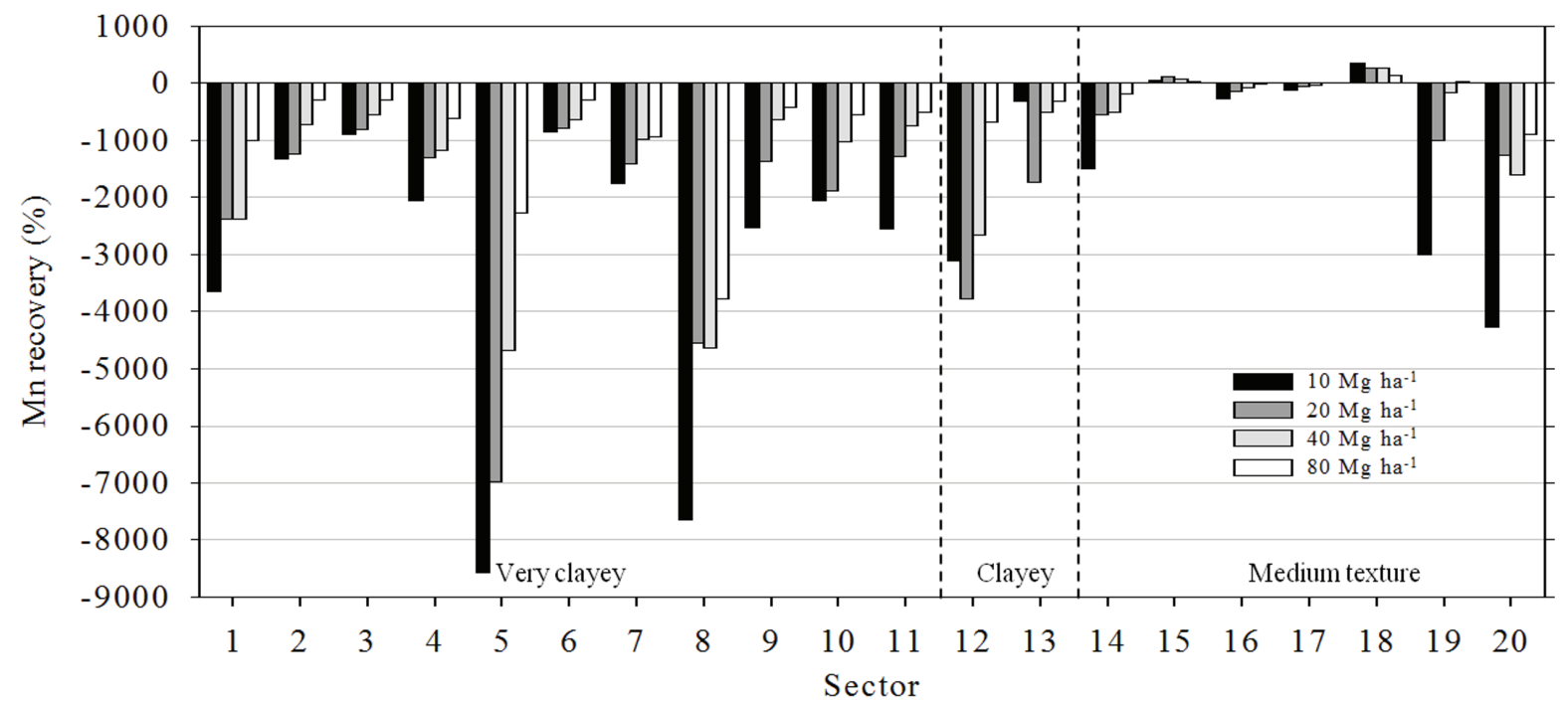

Figure 3: Manganese recovery (\%) (Mehlich-1 extractor) from soils treated with alkaline sewage sludge from Paraná, Brazil. Sector: 1 - Apucarana; 2 - Cascavel; 3 - Campo Mourão; 4 - Francisco Beltrão; 5 - Foz do Iguaçu; 6 - Guarapuava; 7 - Londrina; 8 - Maringá; 9 - Pato Branco; 10 - Pinhais; 11 - Toledo; 12 - Cornélio Procópio; 13 - Santo Antônio da Platina; 14 - Arapongas; 15 - Matinhos; 16 - Ponta Grossa; 17 - Rio Negro; 18 - Telêmaco Borba; 19 - Paranavaí; 20 - Umuarama.

The positive Mn recovery occurred in two soils (Matinhos and Telêmaco Borba) (Figure 3), and these soils showed good Mn content and low availability, respectively (Table 6). However, the level of interpretation changed (high) only for Telêmaco Borba soil. Thus, in these two soils, applications of alkaline sewage sludge had no significant impact as a Mn source. It is worth noting that the $\mathrm{Mn}$ deficiency has been observed especially in soils receiving excessive liming (Tanaka; Mascarenhas; Bulisani, 1993) or in systems that favor the accumulation of organic matter, such as the no-tillage system (Moreira et al., 2016).

\section{CONCLUSIONS}

The alkaline sewage sludge from Paraná state had a distinct effect on the three micronutrients. There was an increase in Zn availability for most soils, especially sandy soils. Available $\mathrm{Cu}$ presented a decrease with alkaline sewage sludge application in very clayey soil, suggesting that the increase in the adsorption/precipitation overlaps via the sludge addition. However, in soils with lower adsorption capacity, the opposite occurs. Therefore, two attributes were keys in the effect of the alkaline sewage sludge $\mathrm{Cu}$ availability, texture and $\mathrm{Cu}$ content in the sludge. The high sensitivity of $\mathrm{Mn}$ to $\mathrm{pH}$ elevation resulted in a decrease in availability. Thus, regardless of the $\mathrm{Mn}$ content in the sludge, raising the $\mathrm{pH}$ decreased the Mn availability.

\section{REFERENCES}

ABREU, C. A. et al. Avaliação da disponibilidade de manganês e ferro em solos pelo uso do método modificado da resina de troca iônica. Revista Brasileira de Ciência do solo. 28(3):579-584, 2004.

ABREU, C. A.; LOPES, A. S.; SANTOS, G. C. G. Micronutrientes. In: NOVAIS, R. F. et al. (eds.). Fertilidade do solo. Viçosa, SBCS, 2007. p.645-736.

ALLOWAY, B. J. Heavy metals in soils. 2.ed. London, Blackie Academic \& Professional, 1995, 368p.

ARIAS, M. et al. Competitive adsorption and desorption of copper and zinc in acid soils. Geoderma. 133:151-159, 2006.

BARCELLOS, M. et al. Atributos químicos de Latossolo sob plantio direto adubado com esterco de bovinos e fertilizantes minerais. Comunicata Scientiae. 6:263-273, 2015.

BERTON, R. S.; NOGUEIRA, T. A. R. Uso do lodo de esgoto na agricultura. In: COSCIONE, A. R.; NOGUEIRA, T. A. R., PIRES, A. M. M. (eds.). Uso agrícola de lodo de esgoto. Botucatu, FEPAF, 2010. p.31-50.

BHERING, S. B.; SANTOS, H. G. Mapa de solos do Estado do Paraná: legenda atualizada. Rio de Janeiro, EMBRAPAIAPAR, 2008. 74p. 
BITTENCOURT, S. et al. Sewage sludge usage in agriculture: A case Study of its destination in the Curitiba Metropolitan Region, Paraná, Brazil. Water, Air and Soil Pollution. 225:2-8, 2014.

BONINI, C. S. B.; ALVES, M. C.; MONTANARI, R. Recuperação da estrutura de um Latossolo Vermelho degradado utilizando lodo de esgoto. Revista Brasileira de Ciências Agrárias. 10(1):34-42, 2015.

BORGES, M. R.; COUTINHO, E. L. M. Metais pesados do solo após aplicação de biossólido. II - Disponibilidade. Revista Brasileira de Ciência do Solo. 28:557-568, 2004.

BRASIL. Ministério do Meio Ambiente. Conselho Nacional do Meio Ambiente. Resolução CONAMA n ${ }^{\mathbf{3 7 5}}$, de 29 de agosto de 2006. Define critérios e procedimentos, para o uso agrícola de lodos de esgoto gerados em estações de tratamento de esgoto sanitário. 2006. Available in: <www.mma.gov.br/port/conama/ res/res06/res37506.pdf>. Access in Jun 9, 2016.

CASAGRANDE, J. C.; SOARES, M. R.; MOUTA, E. R. Zinc adsorption in highly weathered soils. Pesquisa Agropecuária Brasileira. 43(1):131-139, 2008.

COSTA, J. M.; OLIVEIRA, E. F. Fertilidade do solo e nutrição de plantas. Cascavel, Campo Mourão: COAMO/COODETC, 1998. 89p.

COMISSÃO DE QUÍMICA E FERTILIDADE DO SOLO - CQFSRS/SC. Manual de adubação e calagem para os Estados do Rio Grande do Sul e de Santa Catarina. 10. ed. Porto Alegre, SBCS - Núcleo Regional Sul/UFRGS, 2004. 400p.

FAN, J. et al. Immobilization of copper in contaminated sandy soils using calcium water treatment residue. Journal of Hazardous Materials. 189(3):710-718, 2011.

FIA, R.; MATOS, A. T.; AGUIRRE, C. I. Características químicas de solo adubado com doses crescentes de lodo de esgoto caleado. Engenharia na Agricultura. 13:287-299, 2005.

HEALY, M. G. et al. Metal concentrations in lime stabilized, thermally dried and anaerobically digested sewage sludges. Waste Management. 48:404-408, 2016.

HUE, N. V.; MAI, Y. Manganese toxicity in watermelon as affected by lime and compost amended to a Hawaiian acid Oxisol. HortScience. 37(4):656-661, 2002.

MARTINS, A. P. L.; REISSMANN, C. B. Material vegetal e as rotinas laboratoriais nos procedimentos químico-analíticos. Scientia Agraria. 8:1-17, 2007.

MELO, E. E. C. et al. Disponibilidade e fracionamento de Cd, Pb, Cu e Zn em função do $\mathrm{pH}$ e tempo de incubação com o solo. Ciência e Agrotecnologia. 32:776-784, 2008.
MILLALEO, R. et al. Manganese as essential and toxic element for plants: Transport, accumulation and resistance mechanisms. Journal of Soil Science and Plant Nutrition. 10(4):470-481, 2010.

MONDAL, S. et al. Changes in soil quality in response to short-term application of municipal sewage sludge in a typic haplustept under cowpea-wheat cropping system. Environmental Nanotechnology, Monitoring and Management. 4:37-41, 2015.

MOREIRA, S. G. et al. Chemical forms in soil and availability of manganese and zinc to soybean in soil under different tillage systems. Soil and Tillage Research. 163:41-53, 2016.

MOTTA, A. C. V. et al. Micronutrientes na Rocha, Solo e na Planta. 1. ed. Curitiba, Edição do Autor, 2007. 246p.

NACHTIGALL, G. R.; NOGUEIROL, R. C.; ALLEONI, L. R. Extração seqüencial de $M n$ e $Z n$ em solos em função do $\mathrm{pH}$ e adição de cama-de-frango. Revista Brasileira de Engenharia Agrícola e Ambiental. 13(3):240-249, 2009.

OLIVEIRA, M. F. G. et al. Relação entre o zinco "disponível", por diferentes extratores, e as frações de zinco em amostras de solos. Revista Brasileira de Ciência do Solo. 23(4):827836, 1999.

PARANÁ. Secretaria de Estado de Meio Ambiente e Recursos Hídricos. Resolução Sema 021/09. Dispõe sobre licenciamento ambiental, estabelece condições e padrões ambientais e dá outras providências, para empreendimentos de saneamento. Diário Oficial do Estado do Paraná, Curitiba, n. 7962, p.13-16. 2009.

PARANÁ. Instituto Ambiental do Paraná. Portaria IAP 256/2013. Aprova e estabelece os critérios e exigências para a apresentação da declaração de carga poluidora, através do sistema de automonitoramento de Atividades Poluidoras no Paraná e determina seu cumprimento. Diário Oficial do Estado do Paraná, Curitiba, 23 de setembro de 2013. Available in: <http://celepar7.pr.gov.br/sia/ atosnormativos/form_cons_ato1.asp?Codigo=2760>. Access in: Jun 10, 2016.

POGGERE, G. C. et al. Lodos de esgoto alcalinizados em solos do estado do Paraná: Taxa de aplicação máxima anual e comparação entre métodos para recomendação agrícola. Revista Brasileira de Engenharia Agrícola Ambiental. 17:429-438, 2012.

PONTONI, D. R. Nutrição e crescimento do feijoeiro (Phaseolus vulgaris L.) em função de lodo de esgoto e calcário para solos subtropicais. Curitiba, PR, 2012. Available in: <http:// acervodigital.ufpr.br/handle/1884/26258>. Access in: November, 08, 2016. 
VAN RAIJ, B. et al. Recomendações de adubação e calagem para o estado de São Paulo. 2. ed. Campinas: IAC, Boletim técnico, 1996. 285p.

RANGEL, O. J. P. et al. Efeito de aplicações de lodos de esgoto sobre os teores de metais pesados em folhas e grãos de milho. Revista Brasileira de Ciência do Solo. 30(3):583$594,2006$.

RESZEL, R.; RESZEL, H.; GLOWACKA, A. Phytoavailability of copper and zinc from soil reclaimed by lime-treated sewage sludge and other waste. Environment Protection Engineering. 33(2):205, 2007.

SAMPAIO, A. O. Adequação das estações de tratamento de esgotos sanitários à resolução número 375 do CONAMA. In: COSCIONE, A. R.; NOGUEIRA, T. A. R.; PIRES, A. M. M. Uso agrícola de lodo de esgoto. Botucatu, FEPAF, 2010. p.256-280.

SOBRAL, L. F. et al. Comparison of copper, manganese, and zinc extraction with Mehlich 1, Mehlich 3, and DTPA solutions for soils of the Brazilian coastal tablelands. Communications in Soil Science and Plant Analysis. 44(17):2507-2513, 2013.
SOUZA, R. A. S. et al. Extração sequencial de zinco e cobre em solos tratados com lodo de esgoto e composto de lixo. Química Nova. 35:308-314, 2012.

SPARKS, D. L. Environmental soil chemistry. San Diego, Elsevier, 2003. 345p.

SMOLDERS, E. et al. The availability of copper in soils historically amended with sewage sludge, manure, and compost. Journal of Environmental Quality. 41(2):506514, 2012.

TANAKA, R. T.; MASCARENHAS, H. A. A.; BULISANI, E. A. Manganese deficiency in soybean induced by excess lime. Better Crops International. 9:1-7, 1993.

TORRI, S. I.; LAVADO, R. Zinc distribution in soils amended with different kinds of sewage sludge. Journal of Environmental Management. 88(4):1571-1579, 2008.

YADA, M. M. et al. Chemical and biochemical properties of oxisols after sewage sluge application for 16 years. Revista Brasileira de Ciência do Solo. 39:1302-1310, 2015. 